\title{
APPLICATION OF UMRA AND RUQBA IN DISBURSEMENT OF FAMILY TAKAFUL BENEFIT: AN ANALYSIS FROM SHARIAH PERSPECTIVE
}

\author{
Md. Habibur Rahman ${ }^{1 *}$, Md. Faruk Abdullah¹, Puspa Liza Ghazali, and \\ Noor Mohammad Osmani \\ ${ }^{1}$ Faculty of Economics and Management Sciences, Universiti Sultan Zainal Abidin, \\ Kampus Gong Badak, 21300 Kuala Nerus, Terengganu, Malaysia \\ ${ }^{2}$ Kulliyyah of Islamic Revealed Knowledge and Human Sciences, International Islamic \\ University Malaysia, P.O. Box 10, 50728 Kuala Lumpur, Malaysia \\ *Corresponding author: habiburrahman@unisza.edu.my
}

Published online: 20 March 2019

To cite this article: Rahman, M.H., Abdullah, M.F, Ghazali, P.L., and Osmani, N.M. (2019). Application of umra and ruqba in disbursement of family takaful benefit: An analysis from shariah perspective. Asian Academy of Management Journal, 24(Supp. 1), 107-123. https://doi.org/10.21315/aamj2019.24.s1.8

To link to this article: https://doi.org/10.21315/aamj2019.24.s1.8

\begin{abstract}
The paper aims to analyse the validity of practicing umra and ruqba concepts in disbursement of family takaful benefit from the shariah perspective. In the current practice of takaful, the disbursement of family takaful benefit is subject to the demise of takaful certificate holder. Upon maturity of the certificate, if the certificate holder is alive, he will enjoy takaful benefit but not the beneficiary or hibah recipient. Accordingly, he takes back the donation that he made earlier, which makes the arrangement contentious, as long as the Islamic value is concerned. To resolve this issue, the paper suggested that the takaful benefit could be disbursed based on umra and ruqba concepts as they are subject to the survival of the contracting parties. Umra and ruqba are valid provided that once the donation is executed, the donated object should never be returned to the donor. These concepts are appropriate for takaful because the beneficiary can enjoy takaful benefit only when the certificate holder dies before the maturity of certificate. Once the certificate holder dies, takaful benefit cannot be provided to him. The paper argues that the application of umra and ruqba concepts minimises the consequential issues that arise when takaful benefit is
\end{abstract}

(C) Asian Academy of Management and Penerbit Universiti Sains Malaysia, 2019. This work is licensed under the terms of the Creative Commons Attribution (CC BY) (http://creativecommons. org/licenses/by/4.0/). 
disbursed by nomination or inheritance or absolute hibah. Analysing the opinions of the classical Islamic jurists, the paper concludes that the application of umra and ruqba in disbursement of takaful benefit could be done with a structured checklist form.

Keywords: conditional hibah, umra, ruqba, disbursement, takaful benefit

\section{INTRODUCTION}

Umra and ruqba are the two well-known forms of hibah that were practiced in pre-Islamic period. Umra refers to a gift in the life of donor or beneficiary subject to the asset being return to the donor after demise of beneficiary. It also denotes a transitory provision which refers to the life of any party of hibah arrangement, either the hibah giver or the receiver. Ruqba on the other hand is a gift which puts demise of either the donor or beneficiary as a condition to possess the hibah object by the existing party. It is a gift subject to a condition defined by the donor whereby the hibah object would be possessed by the beneficiary in the event that the demise occurs to the hibah giver (Muda, 2008).

Takaful benefit refers to the proceeds of family takaful arrangement which comprises of participant's contribution in the investment account along with the profit, if any, as well as claim or compensation from the risk account pooled from participant's tabarru' portion (Bank Negara Malaysia, 1984). Generally, takaful proceeds are associated with the demise of participant and maturity of takaful plan. If the participant exists upon maturity of the takaful plan, the participant will obtain the takaful profit. However, if the participant dies prior to maturity of takaful certificate, takaful benefit shall be given to the person assigned by the participant.

There are several possible modes to disburse the takaful benefit among the intended beneficiaries, in the case of demise of the participant prior to the maturity of takaful certificate. Hence, takaful benefit may be disbursed by assigning someone as a nominee to collect the benefit and to distribute among the intended beneficiaries. Also, the takaful benefit could be disbursed among the intended beneficiaries according to the inheritance distribution system. Moreover, it also could be disbursed by making an absolute hibah to the intended beneficiary.

However, each of these possible modes has shortcomings. They are not compatible with the purpose of takaful plan. The reason for participating in family takaful arrangement is to generate an immediate wealth in the case of untimely death of a wage earner. It is also a part of risk management process which is in line 
with shariah. In the case of assigning the nominee, he/she could or could not be a beneficiary subject to the legal framework. In many regulations, the nominee will be a beneficiary if he/she is the legal spouse or child of the deceased which is insured. Sometimes this process goes through long administrative delays of estate administration that may prejudice the objective of takaful scheme (Ismail, 2009). Moreover, in the case of allocating takaful benefit pursuant to the Islamic inheritance law, the basic objective of takaful plan might be overlooked. In this situation, takaful benefit might probably be disbursed to the inheritors who are not actually affected by the death of insured participant. Also, if takaful benefit is considered as bequest, it would be subjected to the fulfilment of some rights and responsibilities that should be fulfilled prior to the allocation to the inheritors, such as the imbursement of funeral costs, and the deceased's loans, which entirely contradicts the objective of takaful plan (Noor \& Asmadi, 2008).

\section{LITERATURE REVIEW}

\section{Umra and Ruqba}

Umra is a unique form of hibah and it requires what all other forms of hibah require, such as the offer, approval, and ownership or what replaces it. In lexical sense, umra means to make something related to the life, derivative from the root word "umr" which means life or age. Tha'lab" said, "umra means giving the house to someone by saying: this is for you subject to your life or mine, whoever of us dies the house will be given to his family" (Ibn Manzur, 1990; al-Razi, 2008). As a juristic term, Hanafi and Hanbali Schools define it as giving someone one's own possession referring to the life of anyone of them (al-Kasani, 2005; Ibn Qudamah, 2004; al-Bahuti, 1997). However, Maliki and Shafi'i Schools defined it as donating someone one's own belonging referring to the life of the recipient (Ibnul Munzir, 1997; al-Nawawi, 2000; Ibn Juzayy, 2005).

Ruqba is a gift contract subject to the life of donor and beneficiary. Whoever dies earlier the other party will enjoy the donation. In fact, ruqba means waiting for the other to die. In lexical sense it is derived from the word "muraqabah" which means, to inspect, oversight, and to observe. This is called ruqba as each party observes and inspects the death of another, so that the donation would be for him (al-Razi, 2008; al-Fayyumi, 1323H). Majority of the scholars define ruqba as a scenario whereby one says to another, "I am giving you this house as ruqba subject to your lifetime, provided that if you die before me the house will return to me and if I die before you the house would be for you and your heir(s)". Maliki School defines ruqba as one's saying to another, "if you die before me your house would 
be for me and if I die before you my house would be for you" (al-Ramli, 1993; al-Shawkani, 2000; Ibn Juzayy, 2005; Ibn Qudamah, 2004).

The two forms of hibah namely umra and ruqba are well known in classical literatures, albeit they have not been paid adequate attention in contemporary literatures and practices. The fiqh encyclopaedia of Kuwait, al-Mawsu'ah al-Fiqhiyyah (Ministry of Awqaf \& Religious Affairs, 1992), had discussed these forms of hibah with juristic analysis. Apart from this, Usmani (2006) had discussed these forms of hibah with profound elaboration in his commentary book on Sahih Muslim.

In addition, one study was done by Noor and Asmadi (2008) on the ownership and hibah issues of takaful benefit in Malaysia. They believe distribution of takaful proceeds according to Islamic inheritance law would not be compatible with the objective of takaful operation. Distribution of takaful benefit to a particular beneficiary in a form of hibah is given preference in the paper and numerous contentious issues over sole beneficiary were highlighted in the paper. Likewise, another study was carried out by Ismail (2009) on assigning the nominee and hibah issues in the disbursement of takaful benefit.

Disbursement of takaful benefit over making it an absolute hibah to the intended beneficiary raises some other unsettled issues. What if the recipient dies after hibah object has been transferred to his/her custody, should it become his/her property, can the beneficiary be changed? What would be if the wife is divorced or died while she is the recipient of the takaful proceeds? Can the husband be the recipient of the benefit of his wife while he is paying a policy for her, or should he just treat a trustee or executor and accordingly her benefit shall be distributed among her legal heir(s) pursuant to the inheritance law? (Noor \& Asmadi, 2008).

Having these constrains, instead of an absolute hibah a conditional hibah in the form of umra and ruqba could be applied to disburse takaful benefit. Thus, such hibah arrangement can be revoked if the stipulated conditions are not fulfilled. Nevertheless, the disbursement with hibah umra and ruqba could be arranged in a checklist form whereby the participant may say, for example, "my wife would be the beneficiary of the benefit of my takaful certificate", provided that he (the participant) is not alive while takaful certificate matures, she is alive upon demise of the participant, she is not divorced, takaful proceed shall be spent for such and such purpose, in the case whereby takaful certificate is taken to serve any specific purpose, e.g. for the education of any kid and so on. However, in that case, the wife may be considered as a trustee/executor if not the beneficiary and any other condition deemed relevant. 
If the beneficiary is the adopted son or someone who is dependent on the deceased, takaful benefit could be disbursed by hibah umra and ruqba provided that the certificate holder is not alive while takaful certificate matures, he/she is alive upon demise of the takaful certificate holder, he/she is still in the custody of the participant, takaful proceed shall be spent for his/her education purpose for instance, and any other condition relevant to the takaful certificate holder.

Hence, this research intended to discuss further the principles of umra and ruqba donations based on the juristic analysis. The study also aimed to investigate the feasibility of their applications to the disbursement of takaful benefit. Responding to the issues mentioned in previous studies, the paper posited the use of conditional hibah, either in the form of umra and ruqba or in any other form deemed relevant, as a mechanism of the distribution of takaful proceeds among the intended beneficiary(s).

\section{DISCUSSION AND ANALYSIS}

\section{Juristic Analysis on Umra}

Muslim scholars opine that as a form of hibah, the arrangement of umra is valid. The Prophet (pbuh) said, "who donates anything relating to the life, i.e., hibah umra, the donated item would be for the beneficiary, irrespective of whether he is alive or dead, and then for his heir(s)" (al-Nisaburi, 2003, hadith no.: 1246). The Prophet (pbuh) further said, "the donation through umra is valid for its beneficiary" (al-Bukhari, 2002, hadith no.: 2483; al-Nisaburi 2003, hadith no.: 1248). Concerning hibah umra, Muslim jurists have different opinions whether it transfers ownership of the asset or ownership of the usufruct only.

According to Hanafi, Shafi'i, and Hanbali Schools, by the donation of umra, the ownership of the asset would be transferred straight away to the beneficiary (al-Kasani, 2005; al-Sarakhsi, 1989; al-Mawardi, 1999; Ibn Qudamah, 2004). Jabir ibn Abdullah reported, the Prophet (pbuh) said, "take care of your property and do not let it to be destroyed". So, whoever makes a donation of umra, the donated object would be for the beneficiary, irrespective of whether he is alive or dead, and subsequently for his descendant (Muslim 1247). On another occasion the Prophet (pbuh) passed the judgment that the donation of umra is for the beneficiary (al-Bukhari, 2002, hadith no.: 2482). 
Maliki School and Layth ibn Sa'd opined that in the arrangement of hibah umra only the beneficiary enjoys the usufruct of object and once he dies the asset returns to the donor. When Qasim ibn Muhammad was asked about umra he said, people follow own terms and conditions in their donation arrangements. Ibrahim ibn Ishaq reported from Ibn al-Arabi that the Arab agrees that in the donation of umra and ruqba the asset will remain in the possession of donor while the usufruct only would be for the beneficiary. Furthermore, the norm in ownership is that it shall not be temporary, as it is not allowed that one buys the thing for a period. Since the ownership of the asset shall not be transitory, in umra donation the word of the donor shall be understood as transferring the ownership of usufruct only as it can be momentary (al-Hattab, 1995; Ibn Rushd, 2003).

Nevertheless, Shafi'i School classified the donation of umra into three categories. First, one says that, "I am donating you this house on umra, if you die it will be for your heirs", such arrangement would be valid, and it is just a hibah contract. Once the person dies, the house would belong to his heirs, if no heir(s) is alive the house will go to the public treasury and never returns to the donor. Second, the donor says, "I make this for you as long as you are alive", and he does not provide further details, and according to the known and later stand (qawl jadid) of Shafi'i School it is valid, and it would be treated as hibah. However, another earlier thought (qawl qadim) of the School opines that it is invalid. Third, the donor says, "I am giving you this house as long as you are alive, when you die it will return to me or to my heirs in case I die"; according to the preferred opinion this would be a valid hibah but the condition would be void. Nonetheless, the less preferred (qawl marjuh) opinion says that such arrangement would be void as it contains an invalid condition (al-Nawawi, 1983, 2000; al-Ramli, 1993).

The Hanbali School, however, does not differentiate among these words. The prominent Hanbali scholar Bahuti said, in all aforementioned scenarios and examples, the hibah would be valid. These are considered hibah umra, where the donated item would be the possession of the beneficiary and afterwards in his absent it would be for his heir(s) if available. If no heir exists, then it will go to the public treasury as like all other residuals (al-Bahuti, 1997).

\section{Shari'ah Ruling of Ruqba}

Ruqba is one form of hibah known to the Arab in pre-Islamic period. As it was practiced, one says to another, "I am making a ruqba donation to you, my land and property subject to your life. If you die earlier, the donated item will return to me and if I die earlier the donated asset will remain in your custody". Muslim jurists differed concerning the validity of hibah ruqba. 
Shafi'i and Hanbali Schools as well as Abu Yousuf of Hanafi School opined that it is valid. The donated object will be for the beneficiary that has been donated and will not return to the donor of ruqba, and accordingly the condition will be void (al-Ramli, 1993; al-Shawkani, 2000; Ibn Qudamah, 2004; al-Bahuti, 1997). This opinion is grounded on the hadith which says, "whoever makes umra donation it will be for the beneficiary, regardless of whether he is alive or dead" (al-Nisaburi 2003, hadith no.: 4283). Do not make ruqba donation, but if one makes ruqba donation it will be for the beneficiary and does not return to the donor (al-Sajistani, 1997). In another narration, the Prophet (pbuh) says that both umra and ruqba donation are valid for their respective beneficiaries (al-Tirmidhi, 2000). So, as the narrations indicate, in umra and ruqba donations the donated asset would be for the beneficiaries of these hibah while the condition of returning back to the custody of donor would be invalid.

Imam Abu Hanifah and Imam Muhammad opined that hibah ruqba is invalid. When the donor says, "if I die before you the object will be for you, and if you die before me it will return to me", is basically making the ownership contingent on risk and danger (i.e., hesitancy in the matter whether it happens or not), and accordingly it would be void (al-Marghinani, 2000; Ibn Abidin, 1998). In addition, there is an opinion from Maliki School that hibah umra is valid whereas hibah ruqba is invalid, grounded on a narration that the Prophet (pbuh) allowed umra and discarded ruqba (al-Zurqani, 2002; al-Zayla'i, 1393H).

To sum up, the donation of umra is valid, but there could be some scenarios. If the donor says to the beneficiary, "this is for you and your descendant", it will be a hibah arrangement in fact. If the donor says, "this is for you as long as you are alive, and once you die it will return to me", it would be considered transitory ariyah (i.e., lending of usufruct without compensation) arrangement. The second thought says it would be treated as hibah and the condition of returning the asset to the donor would be considered ineffective. Also, if the donor says, "this is hibah umra for you" without providing further details, this would be concluded as hibah and the asset will not return to the donor. Nonetheless, in these scenarios umra would be considered perpetual hibah and accordingly possession of the property will be moved to beneficiary and never returns to the donor. However, Maliki Schools opines that only ownership of the usufruct will be transferred. Thus, after the demise of beneficiary and his heirs the asset will return to the donor. The donation of ruqba will also be treated as that of umra. 


\section{Juristic Analysis on Conditional Hibah}

Conditional hibah refers to a form of hibah where the execution of hibah is contingent upon a clause which is not in existence but rather likely to exist. For instance, one says, "if you pass the examination I will gift you my watch". So, the execution of hibah depends on such which may or may not exist. Any contract hinging on a condition shall be executed once the condition is actualised. This is because if the action would be taken before the condition takes place it would lead to the existence of contingent fact without condition and that is impractical. If the execution of hibah is made conditional on a future time, such as the beginning of next week or next month this is called hibah mudafah ila al-mustaqbal, i.e., hibah contingent upon the future (Ministry of Awqaf \& Religious Affairs, 1992). Muslim jurists differed on the validity of such conditional hibah as follows.

Majority scholars of Hanafi, Shafi'i, and Hanbali Schools as well as Ibn Hajm opine that making hibah contingent on a future clause is not valid. The fundamental rule of the contracts that transfer the ownership is immediate execution. Hibah is one of the contracts that denote transfer ownership and thus it requires immediate implementation. Making hibah hinging on a future condition is inconsistent with its fundamental nature (al-Kasani, 2005; Ibn Qudamah, 2004; al-Mardawi, 1997; Ibn Hazm, 1900). Thus, if hibah is made subject to a condition it is valid, but if the condition is invalid consequently ownership will be transferred to the beneficiary. However, some other scholars of Hanafi and Hanbali Schools opine that, in a conditional hibah, both contract and condition are valid. Making the sale contract hinging on a clause is valid, so making hibah with a condition, which is a voluntary contract, would be valid as well (Ministry of Awqaf \& Religious Affairs, 1992).

Scholars of Maliki School allow making a promise in hibah as it is a voluntary contract, albeit they opine that contracts which transfer the ownership shall not be associated with any future condition. It is based on the prominent saying of Imam Malik that, "whoever makes commitment of doing any good it is binding for him to execute except at death or insolvent" (al-Qarafi, 1998; al-Kharshi, 1997).

Ibn Taymiyyah preferred the opinion of the validity of conditional hibah. Refuting the opinion says making the hibah contingent upon a clause is invalid, Ibn Qayyim says that, the ruling of the invalidity of conditional hibah is underpinned neither by any text of shariah nor by the consensus of scholars. Hence, what is the evidence on the invalidity of conditional hibah? It is reported from the Prophet (pbuh) that he practiced conditional form of hibah as narrated on the authority of Jabir, the Prophet (pbuh) said to him, "if it had come fund from Bahrain I would give you so 
and so" (al-Bukhari 4122), and later on after the departure of the Prophet (pbuh), when the fund from Bahrain came Abu Bakar implemented that. Nonetheless, if it is argued that it was just a promise (wa'd), it would be said: yes, the conditional hibah is basically a promise. Alike that, same practice has been reported from the Prophet (pbuh) when he was sending musk as a gift to the Najashi, the king of the Ethiopia, he said to Umm Salmah: "I sent to Najashi a suit and ounces of musk, but I have seen that Najashi has died and my gift has been returned back. So, if it would be returned back it will be for you" (al-Hakim, 1990). Pursuant to these two narrations it can be judged that making hibah in conditional form is valid (Ibn Qayyim, 2004).

The authors prefer that making a hibah contract contingent on a future clause is valid. However, such condition shall affirm the requirements of contract and shall be consistent with provisions of the contract. If condition becomes incompatible with provisions and requirements of hibah contract such condition would be invalid.

\section{Existing Takaful Benefit Distribution Practice}

In family takaful, the proceeds from takaful comprise of both participant's contribution in investment account along with the related profit and compensation from risk account pooled from participant's tabarru' portion. According to the Takaful Act 1984, Section 2:

Takaful benefits encompass any profit, pecuniary or not, which is guaranteed by a takaful plan, and 'pay' and other terms, where used in relation to takaful benefits, shall be understood accordingly (Bank Negara Malaysia, 1984).

Generally, takaful profits are associated with the demise of participant and maturity of takaful arrangement. Upon maturity of takaful plan, if the participant exists he shall be paid takaful benefit. However, if he (the participant) dies prior to maturity of takaful certificate, the takaful profits shall be paid to the person assigned by the participant. If a participant dies before his family and the takaful certificate becomes matured, he shall be paid the following takaful benefits:

1. The sum amount of takaful instalments which the participant paid from the beginning of his takaful plan until the end of instalment payment before his demise and his portion of profits from investment of the instalments that have been credited into participant's account. 
2. The remaining takaful instalments which the departed participant would have paid if he survives. This remaining sum is calculated from the day of his demise to the day of maturity of his takaful scheme that will be paid from the participant's special account, as all the participants agreed thereon pursuant to the takaful agreement.

If a participant is alive upon maturity of his takaful certificate, he will be paid the following takaful benefits:

1. The sum amount of takaful instalments that the participant paid within the duration of his participation along with his portion of profits from the investment of the takaful instalments credited into participant's accounts.

2. The net surplus allocated to participant's special account as shown in the last valuation of the participant's special accounts.

\section{Problems with Various Modes to Disburse Takaful Benefit Nomination}

As practiced in insurance, the nomination is assigning or appointing a person to collect policy moneys payable once the policy owner has died. Concerning this, the nominee could or could not be a beneficiary. In many regulations, the nominee will be a beneficiary if he/she is the legal spouse or child of the deceased which is insured. Hence, the issue of assigning a nominee in takaful could be determined by understanding its legal context and framework. One issue that is not addressed in many jurisdictions is whether the takaful company is obliged to settle the takaful benefits to the nominee, even in Malaysia, both the Takaful Act 1984 and the Insurance Act 1963 do not contain any provision to enforce insurance or takaful companies to settle the payment to the nominee, regardless whether the nominee is a beneficiary allowed to enjoy the benefits or not (Ismail, 2009).

Similar to life insurance, the reason of assigning nominee in takaful is to guarantee that the beneficiaries of the participant can enjoy the takaful earnings as fast as possible without going through the long administrative delays of estate administration as it is not subjected to the Probate and Administration Act 1959 and the Will Act 1959. Hence, in the case where there is nomination, the takaful company must pay to the nominee, whether or not the nominee is the beneficiary and that the takaful company shall be free from all liability in respect of the amount paid. This is to make sure that the relatives of the participant have instant access to financial support in the intervening period prior to eventual allocation of the estate. 


\section{Tarikah (Bequest)}

The disbursement of takaful benefits at the demise of takaful certificate holder prior to the maturity of a takaful certificate apparently will be for the departed certificate holder's lawful inheritors, based on that it is the outcome of the deceased's endeavour and accordingly is part of his bequest. Despite the money comes into reality only after the participant's death, it is the endeavour of the participant by entering into the contract, which provides the financial support for his lawful inheritors upon his demise (Noor \& Asmadi, 2008).

However, takaful arrangements create the responsibility upon the operator to settle, they do not generate assets in the insured's possession, but rather they realise a compulsion to lighten the load suffered because of the losses of fellow participants. The participant's contribution in his/her donation for the good of other, not for himself and therefore it is different from other forms of wealth, which is intentionally determined by the deceased for his own benefit. The earnings payable will be for the fund on behalf of the participants, not the takaful company (Noor \& Asmadi, 2008).

Thus, making the selected nominee obliged to allocate funds amid the lawful inheritors of the deceased participant is not compatible with the purpose of takaful plan, and moreover it is not grounded on any convincing opinion. Similar to the life insurance, the rationale of family takaful is to generate an immediate wealth in the case of untimely death of a wage earner. This is in accordance with shariah as the Prophet (pbuh) says, "it is better to leave the inheritors rich than to leave them deprived begging from others (muwatta)". It is also a part of risk management process which is in line with Islamic teachings. Even though by principle, takaful profits are subject to Islamic inheritance law, Islam permits the person to spend his/her asset within his/her life duration. Moreover, if money that will be paid by the takaful operator is allocated amid the lawful inheritors pursuant to the Islamic inheritance law, the fundamental reason and aim of takaful might be overlooked as the money might probably be allocated in favour of inheritors who are not actually affected by the death of insured participant.

It is to be noted that a lawful inheritor is not essentially needy for the wealth of the takaful certificate holder. The dependants of the dead are usually those who relied financially for their lives and maintenance upon the person departed. This could encompass adopted sons and daughters who may be in actual necessity of deceased's financial assistance for things like education, etc. It could also encompass the relatives who are not inheritors, but because of his/her kindness, the deceased willingly helped them particularly in term of schooling. These kinds 
of people are excluded from inheritance according to the Islamic inheritance law. Hence, excluding these dependents from enjoying any portion of takaful proceeds, and encompassing those who are not affected financially by the demise would not be compatible with the rationale of exercising takaful operation (Noor \& Asmadi, 2008).

Apart from this, if takaful benefits are considered the inheritance of deceased, then the money would be subjected to the fulfilment of some rights and responsibilities that should be fulfilled prior to the allocation to the inheritors, such as the imbursement of funeral costs, and the deceased's loans. This would denote that the reimbursement is not being used to lighten the hardship of the family rather it seems other associate participants are under an obligation to resolve the loans of the deceased. In this regard, the creditors will get priority over the participant's dependants. The dependants would only get the benefits after the creditors' claims have been settled (Noor \& Asmadi, 2008).

\section{Hibah}

The question arisen here is whether participants can forgo the takaful proceeds as hibah to a particular beneficiary. One feasible rationale against this is that, the takaful earnings are not available upon the moment when hibah is implemented. However, there are dissimilarities between takaful profits and the item that are considered void to be given as gifts. All the void items mentioned, such as fruits that are not ripened, the children of a sheep, an unborn calf, flour in the form of wheat and butter within milk cannot be quantified whereas the takaful profits are clearly specified and defined. Hence, no such ignorance and uncertainty therein that may lead to the dispute. Therefore, the Shari'ah Advisory Council, Malaysia, has resolved in its 34th assembly on 21 April 2003 that:

The takaful proceeds could be disbursed as hibah since the purpose of takaful is to offer coverage for takaful participant. As the takaful profits are the rights of takaful participant, the participant has freedom to apply his right according to the shari'ah (Bank Negara Malaysia, 2010).

Dallah al-Barakah is also with the same opinion albeit with a different justification. It says:

It is permitted to disburse the takaful proceeds pursuant to the inheritance law of Islam. It is also allowed to allocate the proceeds among the specific people or groups specified by the participant 
on the principle that the proceeds are the contributions of other participants to the beneficiary as defined by the participant not his estate (Barakah Groups, 1997).

A consequential issue whether a hibah of takaful earnings can be terminated without the approval of the nominee or the trustee. In this concern, there seems to be a difference of arguments on the termination of gifts. As the preferred opinion, revocation is not allowed in hibah after being executed. The Prophet (pbuh) says, "the person who terminates his gift is like the dog that licks its vomit" (al-Nisaburi, 2003, hadith no.: 4261). Another narration says, "the donor shall not terminate his gift except when the father makes gift to his son" (al-Tirmidhi, 2000, hadith no.: 2279).

Furthermore, there are some other unsettled issues over making hibah to a sole beneficiary, such as: what if the recipient died after hibah object has been transferred to his/her custody, should it become his/her property, can the beneficiary be changed? What would be if the wife is divorced or died while she is the recipient of the takaful proceeds? Can the husband be the recipient of the benefit of his wife while he is paying a policy for her, or should he just treat a trustee or executor and accordingly her benefit shall be distributed among her legal heir(s) pursuant to the fara'id law? (Noor \& Asmadi, 2008).

\section{Application of Hibah Umra and Ruqba in Takaful Benefit Disbursement}

Referring to the discussion made in the earlier part of this paper, making hibah in a conditional form is a valid arrangement. As to the takaful proceeds the conditional hibah could be proposed rather than the absolute hibah, as it may minimise the issues arisen thereof. In a conditional form hibah will not be executed unless the condition(s) has been met. Hence, such arrangement can be revoked if the condition is not fulfilled or the recipient violates the condition, as the contract is yet to be concluded.

Regarding the disbursement of takaful benefit such arrangement of conditional gift can be in a checklist form such as: The participant may say that, "my wife would be the beneficiary of the benefit of my takaful certificate", provided that:

- $\mathrm{He}$ (the participant) is not alive while takaful certificate matures.

- She is alive at the time of participant's demise.

- She is not divorced. 
- It shall be spent for this such and such purpose, in the case whereby takaful certificate is taken to serve any specific purpose, e.g., for the education of any kid and so on. Of course, in that case the wife may be considered as a trustee/executor if not the beneficiary.

- Any other condition deemed relevant.

If the beneficiary is the adopted son of the deceased, or some other person who is dependent on the deceased the arrangement can be made that, the benefit of this takaful certificate would be given to so and so, provided that:

- The certificate holder is not alive while takaful certificate matures.

- $\mathrm{He} / \mathrm{she}$ is alive at the time of the demise of the takaful certificate holder.

- $\mathrm{He} / \mathrm{she}$ is still in the custody of the participant.

- It shall be spent for his/her education purpose for instance.

- Any other condition relevant to the takaful certificate holder.

In takaful arrangement the disbursement of the takaful benefit is subject to the demise of the certificate holder. If he is alive upon maturity of takaful plan he will enjoy the takaful proceeds, not the beneficiary or recipient of hibah. To accommodate this arrangement, hibah umra and ruqba could be proposed, as these forms of hibah are subject to the survivorship of the parties in the contract. These are valid arrangements, as discussed in the earlier part of this paper, provided that the hibah object shall not return back in the custody of donor after hibah is executed. Surely such condition would be applicable in the takaful arrangement, since takaful benefit will only go to the beneficiary if the certificate holder dies upon maturity of the takaful plan. Hence, the proceeds will never return to the certificate holder as he is already dead. In this case stipulation of the contract could be like this; such as the certificate holder would say, "I am making hibah umra and ruqba of the benefit of my takaful certificate to so and so subject to my demise and his/her survival".

\section{CONCLUSION}

Hibah umra and ruqba are the two conditional forms of donations that were familiar in pre-Islamic period. The Prophet (pbuh) permitted these forms of donations while invalidated the condition of returning the donation to the donor. Umra is donating something subject to the life of the beneficiary and once he dies the object shall be given back to the donor. Ruqba is making a donation with the condition of life of 
the beneficiary. Thus, if the beneficiary survives upon demise of the donor he will be entitled to enjoy the donation. The Prophet (pbuh) judged that umra and ruqba donations are lawful for their beneficiaries and after demise of the beneficiaries the donated objects will go to their heirs and they are never returned back to the donors and their heirs.

In takaful arrangement the disbursement of the takaful benefit is subject to the demise of the certificate holder. If he lives upon maturity of the takaful plan he enjoys the takaful proceeds, not the beneficiary or recipient of hibah. To accommodate this arrangement hibah umra and ruqba could be proposed, as these forms of hibah are subject to the survivorship of the parties in the contract. They are valid arrangement, as discussed in the earlier part of this paper, provided that the hibah object shall not be returned back to the custody of the donor after hibah is executed. This condition is relevant to the takaful arrangement because takaful benefit goes to the beneficiary only if the certificate holder dies upon maturity of the takaful plan. Hence, the proceeds will never return to the certificate holder as he is already dead. In this case, the certificate holder may say, "I am donating the benefit of my takaful certificate as umra and ruqba to so and so subject to my death and his/her survival upon my demise".

Thus, the conditional hibah is valid provided that the restrictive clause shall be adjustable and consistent with the contract and it shall not go beyond shariah principles. As the conditional form of hibah, the arrangement of umra and ruqba is valid while the condition of returning back the hibah object to the donor will be ignored. Application of hibah umra and ruqba will resolve the ownership and distribution issue of takaful benefit without contradicting with the purpose and objective of takaful exercise. Therefore, it is suggested to the takaful industry to practice umra and ruqba concepts with the above-mentioned structured checklist in their underwritings.

\section{ACKNOWLEDGEMENTS}

This research is carried out with the funds of research grant namely Dana Penyelidikan Universiti-DPU (UniSZA/2018/DPU/04), provided by the Research Management, Innovation and Commercialization Centre (RMIC) of Universiti Sultan Zainal Abidin (UniSZA). The authors are grateful to the RMIC, UniSZA. 


\section{NOTE}

1. He was an eminent scholar in Arabic lexicology and grammar, known as Tha'lab. His full name was Abul Abbas Ahmad bin Yahya (815-904 AD). He authored many books in Arabic lexicology and grammar namely, al-Fasih, al-Masun, Ikhtilaf al-Nahwiyyin, I'rab al-Qur'an, Ma'ani al-Qur'an wal Qira'at and so forth.

\section{REFERENCES}

Al-Bahuti, Mansur ibn Yunus. (1997). Kashshaf al-Qina' an Matan al-Iqna'. Beirut: Dar al-Kutub al-Ilmiyyah.

Al-Bukhari, Muhammad ibn Isma'il. (2002). Sahih al-Bukhari. Beirut: Dar al-Kutub al-Ilmiyyah.

Al-Fayyumi, Ahmad ibn Muhammad. (1323H). Al-Misbah al-Munir fi Gharib al-Sharh al-Kabir. Egypt: Maktabat Abd al-Wahid.

Al-Hakim. (1990). Al-Mustadrak. Beirut: Dar al-Kutub al-Ilmiyyah.

Al-Hattab, A.A.M. (1995). Mawahib al-Jalil li Sharh Mukhtasar al-Khalil. Beirut: Dar al-Kutub al-Ilmiyyah.

Al-Kasani, A.U.A.B. (2005). Bada 'i' al-Sanai' fi Tartib al-Shara 'i'. Cairo: Dar al-Hadith.

Al-Kharshi, Muhammad ibn Abdullah. (1997). Sharh al-Kharshi ala Mukhtasar al-Khalil. Beirut: Dar al-Kutub al-Ilmiyyah.

Al-Mardawi, Ala al-Din. (1997). al-Insaf fi Ma'rifat al-Rajihmin al-Khilaf ala Madhhab al-Imam Ahmad ibn Hanbal. Beirut: Dar al-Kutub al-Ilmiyyah.

Al-Marghinani, Ali ibn Abi Bakar. (2000). Al-Hidayah, Sharh Bidayat al-Mubtadi. Cairo: Dar al-Salam.

Al-Mawardi, Abul Hasan Ali ibn Muhammad. (1999). Al-Hawi al-Kabir fi Fiqh Madhhab al-Imam al-Shafi'i. Beirut: Dar al-Kutub al-Ilmiyyah.

Al-Nawawi, Sharaf al-Din. (1983). Sharh Sahih Muslim. Beirut: Dar al-Fikr.

Al-Nawawi, Sharaf al-Din. (2000). Rawdat al-Talibin. Cairo: Al-Maktabat al-Tawfiqiyyah. Al-Nisaburi, Muslim ibn al-Hajjaj. (2003). Sahih Muslim. Beirut: Dar al-Kutub al-Ilmiyyah. Al-Qarafi, Sihab al-Din. (1998). Al-Furuq. Beirut: Dar al-Kutub al-Ilmiyyah.

Al-Ramli, Shams al-Din. (1993). Nihayat al-Muhtajila Sharh al-Minhaj. Beirut: Dar alKutub al-Ilmiyyah.

Al-Razi, Muhammad ibn Abi Bakar. (2008). Mukhtar al-Sihah. Beirut: Dar Sadir.

Al-Sajistani, Sulayman Ibn al-Ash'ath. (1997). Sunan Abi Daud. Beirut: Dar Ibn Hazm. Al-Sarakhsi, Muhammad Ibn Ahmad. (1989). Kitab al-Mabsut. Beirut: Dar al-Ma'rifah. Al-Shawkani, Muhammad ibn Ali. (2000). Nayl al-Awtar. Beirut: Dar Ibn Hazm. Al-Tirmidhi, A.I. (2000). Sunan al-Tirmidhi. Beirut: Dar al-Kutub al-Ilmiyyah. Al-Zayla'i, Jamal al-Din. (1393H). Nasb al-Rayah li Ahadith al-Hidayah. Beirut: alMaktab al-Islami.

Al-Zurqani. (2002). Sharh al-Zurqani ala Mukhtasar al-Khalil. Beirut: Dar al-Kutub alIlmiyyah. 
Bank Negara Malaysia. (1984). Takaful Act 1984. Retrieved February 2018 from http://www.bnm.gov.my/documents/act/en_takaful_act.pdf

Bank Negara Malaysia. (2010). Shariah resolutions in Islamic finance. Kuala Lumpur: n.pub.

Barakah Groups. (1997). Barakah fatwas for Islamic economics. Jeddah: n.pub.

Ibn Abidin, Muhammad Amin. (1998). Radd al-Muhtar ala al-Durr al-Mukhtar. Beirut: Dar Ihya al-Turath.

Ibn Hazm. (1900). Al-Muhalla. Beirut: Dar al-Fikr.

Ibn Juzayy, Abu al-Qasim. (2005). Al-Qawanin al-Fiqhiyyah. Cairo: Dar al-Hadith.

Ibn Manzur, Muhammad ibn Makram. (1990). Lisan al-Arab. Beirut: Dar Sadir.

Ibn Qayyim. (2004). Ighathat al-Lahfan. Cairo: Dar al-Hadith.

Ibn Qudamah, Muwaffaq al-Din. (2004). Al-Mughni. Cairo: Dar al-Hadith.

Ibn Rushd, Muhammad. (2003). Bidayat al-Mujtahid. Beirut: Dar al-Kutub al-Ilmiyyah.

Ibnul Munzir, Muhammad ibn Ibrahim. (1997). Al-Iqna'. Beirut: Dar al-Kutub al-Ilmiyyah.

Ismail, A. (2009). Nomination of hibah issues in takaful industry. Paper presented at the ISRA Shari'ah Conference on Takaful 2009, 7 May 2009. Kuala Lumpur: ISRA (International Shariah Research Academy for Islamic Finance).

Ministry of Awqaf \& Religious Affairs. (1992). Al-Mawsu'ah al-Fiqhiyyah. Kuwait: Ministry of Awqaf \& Religious Affairs.

Muda, M.Z. (2008). Instruments of hibah and wills: Analysis of the regulations and applications in Malaysia. Paper presented at the Hibah and Faraid National Convention 2008, 7 August 2008, Wilayah Mosque, Kuala Lumpur, Malaysia.

Noor, A., \& Asmadi, M. (2008). Takaul (Islamic insurance) benefit: Ownership and distribution issue in Malaysia. Journal of Islamic Economics, Banking and Finance, 5(3), 35-48.

Usmani, Muhammad al-Taqi. (2006). Takmilah Fath al-Mulhim. Damascus: Dar al-Qalam. 